\title{
History OF STUDIES OF ROMAN TIME TYRAS MATERIAL CULTURE
}

OLEG SAVELIEV

\section{REZUMAT: ISTORICUL STUDIERII CULTURII MATERIALE DIN TYRAS ÎN PERIOADA ROMANĂ}

Prima perioadă (al doilea sfert al secolului al XIX-lea - sfârşitul secolului al XIX-lea) se caracterizează prin acumularea materialelor antice obținute în cele mai multe cazuri ca urmare a unor descoperiri întâmplătoare. În mare parte au fost studiate inscripțiile și monedele grecești și latine. În a doua perioadă (1900-1940), au demarat cercetările arheologice din Tyras care au pemis identificrea straturilor culturale, s-a realizat publicarea rezultatelor săpăturilor, au fost făcute observații istorice de natură generală. A treia perioadă (anii 40 - începutul anilor 60 ai sec. XX) este asociată cu începutul unui studiu sistematic al sitului. Au fost descoperite complexe importante de construcție și de producție. A început sistematizarea materialului arheologic. Au fost formulate problemele specifice orașului legate de economie, comerț, relațiile etnoculturale cu lumea exterioară. În perioada următoare (sfârșitul anilor 60 ai secolului XX și până în prezent), au fost efectuate observații pertinente privind stratigrafia monumentului și limitelor sale, a fost acumulată o colecție reprezentativă de materiale, care sunt introduse activ în circulația științifică.

\begin{abstract}
:
The first period (the second quarter of the $19^{\text {th }}$ - the end of the $19^{\text {th }}$ centuries) has been characterized by a long but unsystematic accumulation of materials represented by chance finds. Mostly Greek and Latin inscriptions and coins have been studied. In the second period (1900-1940), the archaeological study of Tyras has begun. They have managed to establish the cultural layers thickness; materials of excavations have been actively published, historical observations of a general nature made. The third period ( $40 \mathrm{~s}$ - early $60 \mathrm{~s}$ of the $20^{\text {th }}$ Century) is associated with the beginning of a systematic study of the site. Important construction and production complexes have been discovered. Systematization of mass material has begun. The questions of economy, trade, ethnocultural relations of the city with the outside world have been raised. In the next period (from the late 60s of the $20^{\text {th }}$ Century until now), high-quality observations of the monument's stratigraphy and its boundaries have been performed, a representative collection of materials has been amassed; the materials collected are being actively introduced into scientific circulation.
\end{abstract}

CUVINTE CHEIE: Imperiul Roman, Tyras, epoca romană, cultura materială, istoricul cercetării.

KEYWORDS: Roman Empire, Tyras, Roman time, material culture, history of studies.

Study of Tyras material culture development is inextricably bound up with archaeological excavation of the site. Several stages could be singled out in the history of the studies reflecting the concept of location of the city, its boundaries, planning, urban development characteristics, economy and contacts with the outer world.

\section{Studies of Archaeological Monuments of Tyras Before Excavation Started (from second quarter to the end of the $19^{\text {th }}$ Century)}

Though archaeological excavations in Tyras started only at the beginning of the $20^{\text {th }}$ Century, interest to the material culture of the city arose in the first part of the $19^{\text {th }}$ Century due to establishing of Odesa Society of History and Antiquities, as well as activities aimed a protection of archaeological monuments, collection and storage of museum pieces. At that time, the first epigraphic documents, architectural details, coins and some other archaeological materials "of artistic virtue" were found. The matters of location of the city and its name have been 
debated on for a long time. The first attempts to localise the site and interpret the artefacts found have been made ${ }^{1}$. It was I.A. Stempkovskij who studied the chance finds from Akkerman, first of all coins with demotikon, and suggested that city Tyras was located just there ${ }^{2}$.

At the same time, studies of lapidary sources of ancient Tyras began and the first attempts to correlate them with narrative sources were made. From time to time «Proceedings of Odesa Society of History and Antiquities» were publishing materials that have been casually found at the territory of medieval fortress and nearby ${ }^{3}$. Based on studies of the materials P.V. Bekker made the conclusion that Tyras was a provincial city subordinated to Roman Emperors, however its citizens were granted some liberties. He also expressed a number of considerations about different sides of the city economy and way of life ${ }^{4}$.

Further on, such publication became more regular. In 1860, the artefacts found during stone quay construction were delivered to Odesa. N. N. Murzakevich reported that the workers have found «a chipped marble statue, a marble torso and an embossed marble tombstone with inscriptions» ${ }^{5}$. In 1866, a circular letter was distributed all over Bessarabia ordering all the local authorities to deliver to the Society of Antiquities the pieces found in land $\mathrm{d}^{6}$. As before, the focus was on epigraphic documents, numismatics and architectural details?

A tombstone of Roman times found between Akkerman and village Shabo was published ${ }^{8}$. N.P. Kondakov, who visited Akkerman, made a list of artefacts found during construction in the coastal area' ${ }^{9}$. A. A. Kochubinskij wrote about finding of tiles with stamps, coins, fragments of marble inscriptions etc. He gave information about burials, one of which contained golden items and two narrow-necked amphorae ${ }^{10}$. The pieces found on the territory of Tyras were delivered to the museum of Odesa Society of History and Antiquities, but much more of them settled in private collections. The collection of I.K. Suruchan contained fragments of inscribed marble slabs, integral painted vessels and amphorae, metalware and coins from Tyras ${ }^{11}$. Visiting Akkerman in 1891, F.I. Knauer bought a ceramic «urn», paste statuette of Isis, coins and a fragment of slab with dedicatory inscription in honour of Egyptian gods ${ }^{12}$. P. M. Batyushkov published a marble fragment with Latin inscription dated the year 201 found near Akkerman ${ }^{13}$. At the same time, the first information about the Tyras necropolis came up. In 1895, A.A. Kochubinskij and E.R. Shtern examined a tomb covered by kurgan - the so-called «Scythian Grave» ${ }^{14}$.

Thus, accumulation and primary processing of casual finds from Tyras and its surroundings was taking place during the first stage, as well as study of ancient authors' evidences about the region. Location of Tyras was reliably established before the end of the $19^{\text {th }}$ Century. Based on the accumulated sources, first of all epigraphic, the first attempts were made to solve some questions connected with history of Tyras, its state system etc.

\section{Beginning of Archaeological Study of Tyras (1900-1940)}

The first archaeological studies in Tyras were performed by E.R. Shtern in 1900, 1903 and 1912. There were 14 test pits and trenches. As the result, stone structures were found, which were interpreted as tombs, fragments of scaffolding, as well as various material of ancient times. It was found that the cultural stratum thickness reached 7 $\mathrm{m}$; movement of the cultural strata and disturbance of the sequence of their occurrence were noted ${ }^{15}$.

These excavations became the basis for further archaeological study of Tyras. E.R. Shtern believed that only the discovery of large areas of the settlement, study of building remains and mass material would help to study the history of that city ${ }^{16}$.

After incorporation of Bessarabia into Romania in 1918, archaeological excavations on the site of the settlement were conducted by Romanian researchers. These works lasted from 1919 to 1937. P. Nicorescu laid three test pits

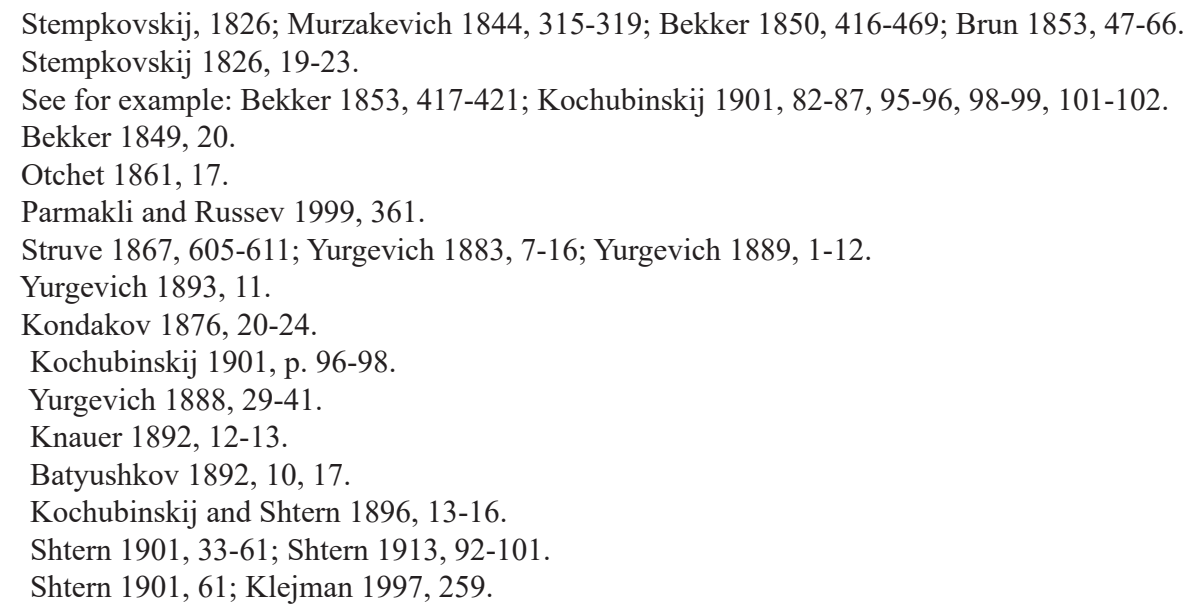


inside the fortress and six pits northeast of the main gate. As the result of this digging, a fragment of the defensive wall, buildings of ancient times, as well as a number of archaeological materials were discovered. P. Nicorescu published the results of the studies in his papers accompanied by plans and illustrative photos ${ }^{17}$. In addition to the publication of the new sources, he touched upon the general issues related to the history of the region. For example, based on the study of legionary tile marks, inscriptions in honour of Emperor Trajan and other information the author not only provided a picture of Roman garrisons location in the North-Western Black Sea, but also clarified the composition of Tyras garrison and changing of its detachments during the $2^{\text {nd }}-$ mid $3^{\text {rd }}$ Centuries $\mathrm{AD}^{18}$.

On behalf of the Military Museum of Bucharest, G. Avakian carried out excavations under the walls of the medieval fortress. Several articles present separate materials - marks on amphorae, tiles with marks of legions, coins, graffiti, etc. ${ }^{19}$ In addition to the medieval strata, he singled out the classical Greek strata and the strata of "prehistoric civilization".

In 1940, after Bessarabia became a part of the USSR, the director of the Akkerman Museum A.V. Shakhnazarov laid an excavation northeast of the fortress central gate. The results of his studies are preserved only in a brief report with two plans ${ }^{20}$. The report contains information about remains of buildings and about finds of Roman times.

In general, digging of that period has been neither large-scale nor systematic or consistent. However, those works formed the basis for further archaeological study of Tyras and improvement of methodology of such studies, in particular, selection of stratigraphic layers.

\section{Archaeological Studies of Tyras and its Material Culture in the $40^{\text {th }}-$ Early $60^{\text {th }}$ of the $2^{\text {th }}$ Century}

In 1945-1946, archaeological studies were carried out by expedition of the Institute of Archaeology (Academy of Sciences of Ukrainian SSR) headed by L.D. Dmytrov. These works marked the beginning of systematic study of the monument using the technique of excavation over large area. In the first two years of the study, the surveys performed earlier were taken into account and all the previous finds were marked on the plan; a new large excavation was laid. The works focused on the area to the east of the medieval fortress main gate. First of all the strata and buildings of the medieval period were studied, however materials of different epochs were also partially introduced into circulation. Brief information about the finds of Roman times was provided ${ }^{21}$.

The studies continued in 1949-1950. The publication presents a detailed description of the objects found, individual findings are of undoubted interest ${ }^{22}$.

Publishing a collection of ceramic stamps from Tyras kept in the Bilhorod-Dnistrovskyi Museum, E.M. Shtaerman briefly touched on some issues of external economic relations of the city in Roman times ${ }^{23}$.

In 1954 and 1958, the settlement was studied by the Bilhorod-Dnistrovskyi detachment of the Prut-Dniester Expedition of the Institute of Archaeology (USSR Academy of Sciences) headed by M.G. Rabinovich. The publication of the excavation results only briefly mentioned finding of Roman lamps, coins, etc. ${ }^{24}$

Significant progress in studies of Tyras material culture of the first centuries AD was connected with the name of A.I. Furmanska, who continued archaeological study of the monument in 1953-1963. She was publishing both the results of excavations and certain categories of finds regularly, at that special attention was paid to Roman time $\operatorname{artefacts}^{25}$. Having studied the ceramic complex, A.I Furmanska divided it into red lacquer, red clay, kitchen, grey clay with polishing, stucco pottery, amphorae, pithoi. Those groups consisted of crockery of different types. Systematization of materials allowed the researcher to raise the issue of the city's cultural and economic ties, touch upon the matter of ethnic changes in population of the Roman period. According to her, the economic recovery lasted from the end of the $1^{\text {st }}$ - beginning of the $2^{\text {nd }}$ to mid- $3^{\text {rd }}$ Century $A D$. Like in previous period, the city maintained close economic ties with the centres of Asia Minor, the appearance in Tire of things that looked barbaric associated with direct cultural contacts ${ }^{26}$.

\footnotetext{
Nicorescu 1924, 378-415; Nicorescu 1933, 557-661.

Nicorescu 1937, 217-239; Nicorescu 1944, 501-510.

Avakian, 1931, 47-104; Avakian 1924, 3-22; Avakian 1927a, 4-17; Avakian 1927b, 35-46.

Klejman 1984, 66-74.

Dmytrov 1952, 59-64.

Dmytrov 1949, 39-52; Dmytrov 1955, 111-123.

Shtaerman 1951, 45, 48-49.

Rabinovich 1968, 106.

25 Furmanskaya and Maksimov 1955, 64-66; Furmanskaya 1964, 56-63; Furmanskaya 1960, 78-83; Furmanska 1965, 158164; Furmanska 1962, 122-137.

26 Furmanska 1957, 80-93.
} 
In 1955, E. V. Maksimov published in his article the results of the study of two furnaces performed in 1953 by Izmail expedition headed by A. I. Furmanska. The bottom of one of the furnaces was lined with flat tiles, two of which contained the marks of the $5^{\text {th }}$ Macedonian Legion; fragments of Roman amphorae were also found there. The bottom of the other furnace also consisted of tiles and bricks, one fragment of a brick bore an image of a ship ${ }^{27}$. The Scientific Archive of the Institute of Archaeology of the National Academy of Sciences of Ukraine keeps the hand-written paper by A. I. Furmanska "Tira pervykh vekov nashei ery" (1962). This is the first generalizing work in which several categories of mass material have been systematized and comprehensively analysed. The main attention was paid to study of a complex of ceramic ware, which the researcher divided into red lacquer, stucco, glossed grey clay, amphorae ${ }^{28}$.

To characterize the late antique stage of Tyras history the information published by A.I. Furmanska ${ }^{29}$ based on the studies of materials from the pits Nos. 6 and 7 was used. She also contributed a chapter to the collection "Ancient City" on the history and culture of Tyras and a part of the collection of archaeological sources relating to building ceramic materials ${ }^{30}$.

In general, this period was characterized by systematic archaeological study of Tyras, writing of scientific reports, publishing of digging results, as well as by analytical papers on various categories of material culture of the city. It was during that period that the first conclusions were made about the historical development of the city, including its latest time of existence.

\section{Archaeological Studies of Tyras from Late $60^{\text {th }}$ of the $20^{\text {th }}$ Century till Present}

The excavations were continued in 1969 by the team of the Institute of Archaeology (Academy of Sciences of the Ukrainian SSR) headed by S.D. Kryzhitskij. The group of researchers from Odesa Archaeological Museum headed by I.B. Klejman took part in the team from 1963 and worked independently in 1965-1968 and 1972-1988. Total area of excavations made $4000 \mathrm{~m}^{2}$.

During these studies, a number of important objects were discovered: first of all, the fortifications should be mentioned: curtains, a round tower and a Roman Vexillatio house, the discovery of a stratum and buildings of late antiquity ("post-Gothic" house), residential and farm buildings of classical, Hellenistic and Roman times, streets etc. Important observations were made regarding the stratigraphy and boundaries of the city; an idea about the Roman citadel was suggested ${ }^{31}$. A significant collection of various categories of materials was amassed, including Roman times: glass, metal, bone and stone, terracotta, red lacquer ware, coins, fragments of pottery with dipinti and graffiti, epigraphic documents with Greek and Latin inscriptions etc. Information related to the necropolis of Tyras was published ${ }^{32}$.

Material and spiritual culture of Tyras was the object of I.B. Klejman's research interest. One of his main interests was coroplastics, however he did not overlook other categories ${ }^{33}$.

Of great importance in the monographic study of P.O. Karyshkovskij and I.B. Klejman is devoted to the history and culture of Tyras in ancient period ${ }^{34}$. This work, which was the conclusion from the previous studies, included a historiographical section, an analysis of available sources and a consistent reproduction of history of the polis development.

The discovery and publication of the so-called. "Post-Gothic" house ${ }^{35}$ was also important for the study of Tyras history of the second half of $3^{\text {rd }}-4^{\text {th }}$ centuries. Determination of chronology of the finds from the complex, primarily amphorae ${ }^{36}$, helped the researchers reconsider the previous viewpoint on the time of life final cessation in the city and to extend it to the $4^{\text {th }}$ Century AD. Thus, this information made it possible to continue the study of the late antique period of $\operatorname{Tyras}^{37}$.

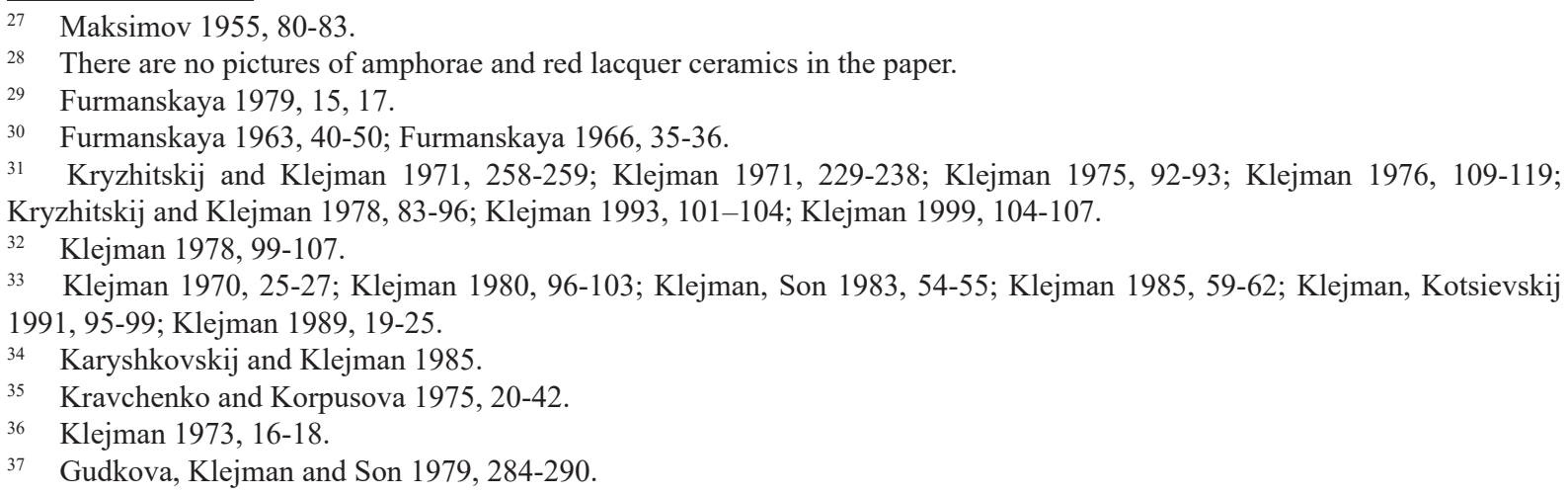


T. L. Samojlova was the author of the generalized work on the study of amphorae dated the Roman times ${ }^{38}$. She divided all the amphorae into two groups, which corresponded to the periodization of the history of Roman Tyras: from the $1^{\text {st }}$ - to the middle of the $3^{\text {rd }}$ and from the middle of the $3^{\text {rd }}$ to the $4^{\text {th }}$ Centuries AD.

The collection of articles devoted to the studies of Tyras and medieval Bilgorod reflected the most important results of research in 1962-1976 ${ }^{39}$. In 1983, an article by I. B. Klejman and N. O. Son was published, which considered the issues of Western Pontic and provincial-Roman cultural and economic ties of Tyras ${ }^{40}$; the article is still important for the study of trade in the first centuries AD. Some fragments of horse harness were mentioned by M. Yu. Trejster, V. M. Zubar and N. O. Son ${ }^{41}$. E. A. Levina and A. S. Ostroverkhov briefly mentioned window glass finding in Tyras ${ }^{42}$.

O. V. Gudkova and V. V. Krapivina published a paper dedicated to the grey clay crockery of Tyras, Olbia and monuments of Chernyakhiv Culture ${ }^{43}$.

In some works, the problems of cultural and economic ties of Tyras with the world of settled barbarians are briefly considered $^{44}$. Based on a set of sources, Yu.V. Pavlenko and N.O Son offered their vision of what Tyras was in the late antique period and what was the nature of Tyras inhabitants' relationship with the Goths ${ }^{45}$.

N.O. Son made a significant contribution to the development of Tyras material culture study. In addition to excavations in Tyras in 1978-1979, 1987-1989, 1990 and 1993, she published a number of works devoted to the study of various categories of artefacts. Based on various archaeological sources, she described the Greek cults of Tyras in the first centuries, examined in detail the remains of buildings and other archaeological materials relating to the late stage of Tyras history ${ }^{46}$. In connection with the new data, T.L. Samojlova also dwelled on the same issue a little later, offering her own vision of the city development in that period, which was different from the viewpoint expressed by the previous author ${ }^{47}$.

In her joint work with S.B. Sorochan, N.O. Son introduced into scientific circulation lamps of different types ${ }^{48}$. The only to-date generalizing article is devoted to the characteristics of the whole set of glassware ${ }^{49}$.

Ye.L. Horokhovskyi and N.O. Son studied one of the most important and informative categories of archaeological material - fibulae ${ }^{50}$. Groups of provincial-Roman and ancient Black Sea forms, as well as Eastern European "barbarian" clasp were identified. It was emphasized that part of the fibulae of those types could have been made locally, as evidenced by the discovery of semi-finished pieces in Tyras.

In 1993, the monograph “Tyras of Roman Times" by N.O. Son was published. It summarized the results of study of the monument. Based on the analysis of epigraphic, numismatic and archaeological sources, the paper examined the issues of the city historical development at that time, its economic life, ethnic composition and spiritual culture of the population. A chapter was devoted to general characteristic of material culture, where the main categories of a ceramic complex, glass, metal and bone products were very succinctly considered ${ }^{51}$.

Interesting results were produced by the discovery of several pottery burners of the first centuries AD - kilns and furnaces ${ }^{52}$. A new idea of the peculiarities of Tyras foreign trade in the first centuries of the new era was also presented $^{53}$.

Some works considered items made of bone ${ }^{54}$. Their nomenclature was presented for the first time. Based on analysis of the objects some conclusions were made about existence of bone-cutting craft in Tyras.

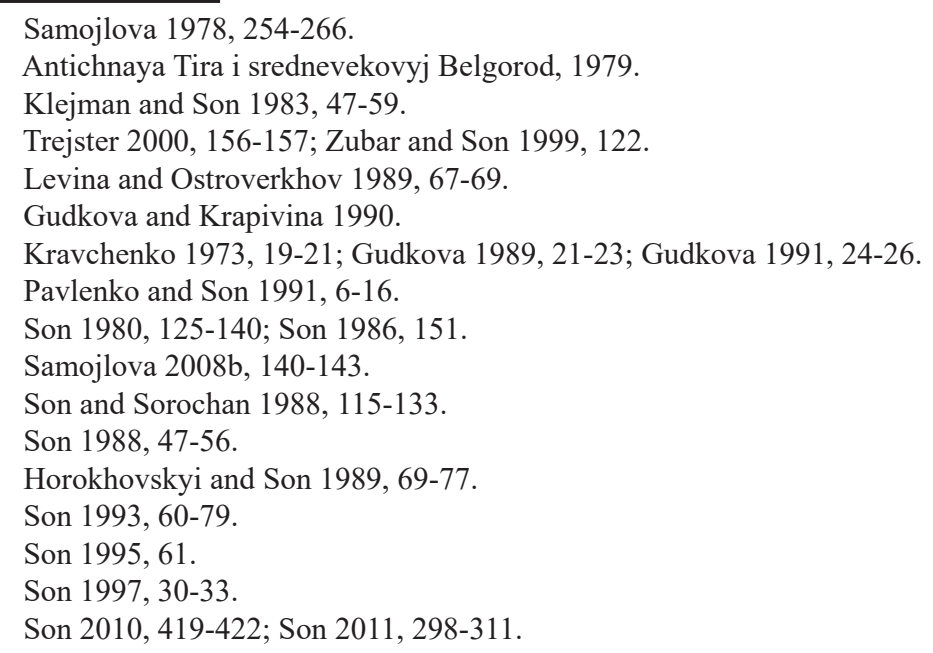


In addition, bone bouterolles from the scabbards of long Roman swords were published and analysed ${ }^{55}$. The article by N.O. Son and M.S. Shaptsev was dedicated to findings of figured vessels ${ }^{56}$.

The article published in 2012 contained the first and so far the only set of red lacquer ware of the first centuries of the new era from Tyras $^{57}$. The authors divided this group of ceramics depending on their shape. The analysis of the vessels allowed distinguishing the eastern sigillata B, C and the late Roman C, the Pontic, Moesian and western sigillata.

Two works consider stucco and metal lamps from Tyras - three bronze ones and one made of lead ${ }^{58}$.

Another vault was discovered to the south-east of Tyras in 1989, the materials were published by ${ }^{59}$.

Useful information on the composition of ancient collection from Tyras excavations hold by the Institute of Archaeology of the National Academy of Sciences of Ukraine were published in the respective catalogue ${ }^{60}$. Clay lamps with nozzles repeating the mouth of an oenochoe-type vessel were addressed by I.V. Bruyako and O.A. Rosokhatskij, who came to the conclusion that the lamps were made locally in the second half of the $2^{\text {nd }}$ - first half of the $3^{\text {rd }}$ Century $\mathrm{AD}^{61}$. S.P. Smolyaninova published foundry moulds for metal ware production, some of which dated back to Roman times ${ }^{62}$.

The Bilgorod-Tyras Expedition of the Institute of Archaeology (National Academy of Sciences of Ukraine) was performing excavations in Tyras for twenty years ${ }^{63}$. New objects dating back to Roman times and late antiquity were discovered in the Central Dig and studied ${ }^{64}$. Work in the garrison courtyard of the medieval Akkerman Fortress confirmed the earlier conclusion that the ancient city extended to that area.

Another collective work was publication of the collection of articles "Tyras Cetatea Albă / Belhorod-Dnistroskyj" in 2002 presenting the results of the five years study of the monument by the joint Ukrainian-Romanian team ${ }^{65}$.

The issues of Tyras people's spiritual life in the ancient period were considered separately ${ }^{66}$. The matters related to the mystical cults in Tyras, in particular in Roman times, were studied by G.V. Batizat ${ }^{67}$. Considering home sanctuaries from the ancient monuments of the Northern Black Sea coast, V.V. Krapivina used the materials from the so-called western house (IV) in Tyras ${ }^{68}$.

Attention was also paid to the study of grey clay vessels ${ }^{69}$. T.L. Samojlova published two articles setting out the main results of recent studies in Tyras $^{70}$. Some pieces of Roman time were published in the overview paper dedicated to the recent excavations in Tyras $^{71}$.

The next summarizing collection of articles, entirely devoted to the study of Tyras and medieval Bilgorod, was published in 2010. It presented, inter alia, articles on various categories of material culture ${ }^{72}$. Another summarizing work on the results of Tyras study was the chapter in the collective monograph "Ancient Cultures of the NorthWestern Black Sea"73.

V.V. Krapivina considered more than once the matters of contacts and peculiarities of Tyras people's relations with representatives of barbarian culture in the late antique period, as well as analysed the materials connected with the Scythian wars period ${ }^{74}$. Some finds of amphorae of the first centuries AD were considered ${ }^{75}$.

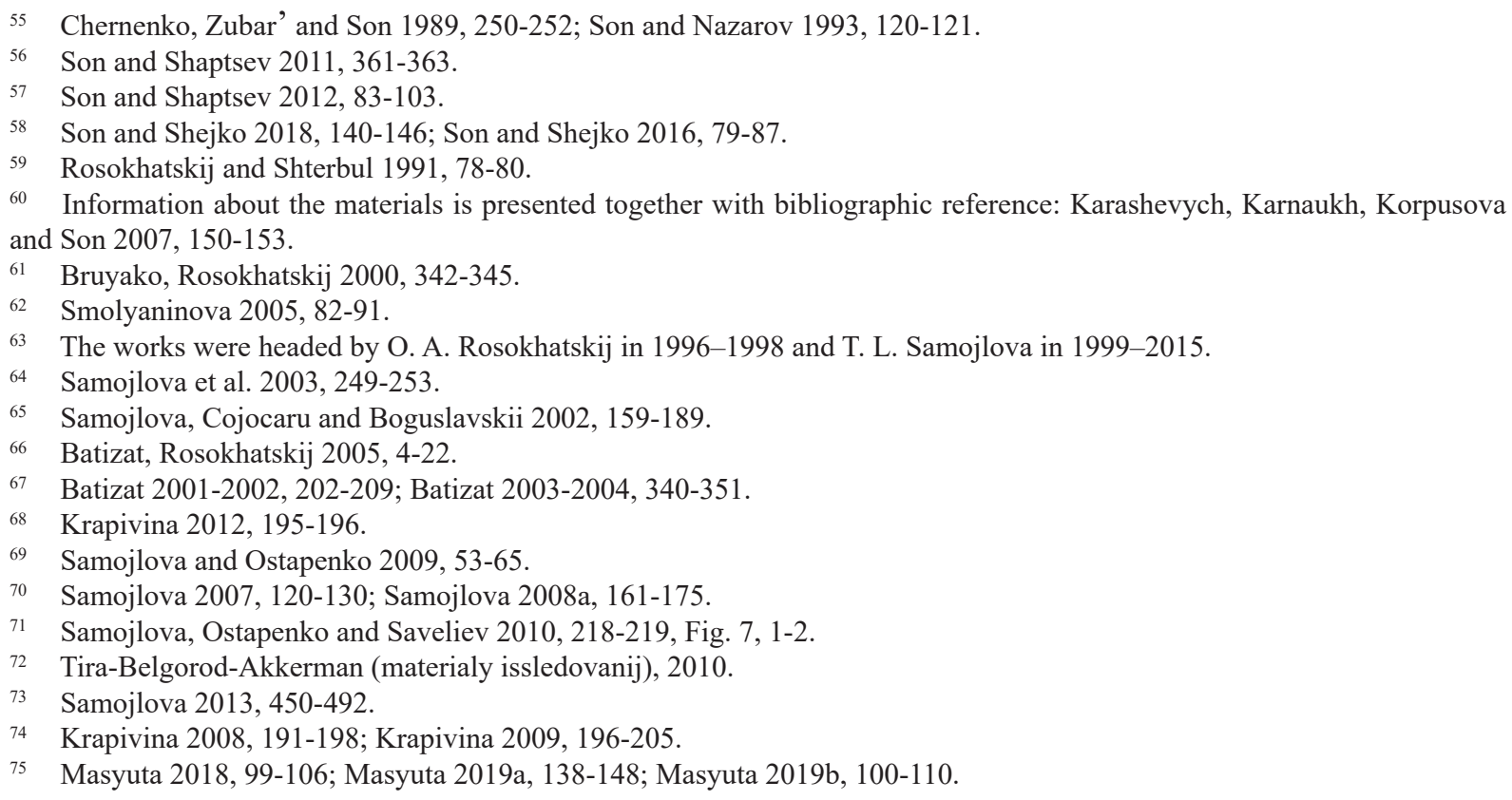


Thus, in the period from the mid-1990s to the mid-2010s, a number of papers by various authors were published raising certain issues of material culture, based on which the matters of urban development, trade connections, barbaric influence etc. were generalized.

In recent years several articles, published by the author, have appeared. They were dedicated to various categories of Tyras material culture, as well as the city's relationship with the outer world ${ }^{76}$.

Thus, the first period in the history of archaeological studies of Tyras and its material culture was characterized by long but unsystematic accumulation of materials, which were represented by chance finds. Mostly Greek and Latin inscriptions and coins were studied. The first works of generalizing nature appeared, which were devoted to the history of the polis, the life of its citizens, and the peculiarities of economy. At the end of the $19^{\text {th }}$ century the location of Tyras was established, systematization of epigraphic and numismatic materials began.

The discovered archaeological and epigraphic data aroused considerable interest in the further study of the monument; there was a need for archaeological excavations, which launched the next period of studies. It became possible to establish the thickness of cultural strata and their movement. Archaeological excavations were published, and some general historical observations made.

The next stage was associated with the beginning of a systematic study of the monument. Important construction and production complexes with interesting material have been discovered. Papers on Tyras history and culture during ancient times appeared. The systematization of mass material started and the issues of economy, trade and ethno-cultural relations of the city with the surrounding world were raised.

The next period is similar to the previous one in respect of field studies methodology. The method of excavations in large areas is still used today. Qualitative observations were made on stratigraphy of the monument and its boundaries during the excavations; a representative collection of materials was amassed. The issues in the field of studying the history of the polis, its economy, production, religion, internal structure, external relations etc. were developed.

Only in recent decades, archaeological material is being dynamically systematized and introduced into scientific circulation. With the active development of research on certain categories of the Roman Era material complex in world science in general, determination of chronology, search for analogues, areas and centres of various artefacts manufacturing became productive.

\section{REFERENCES}

Antichnaya Tira 1979. Antichnaya Tira i srednevekovyi Belgorod. Kiev: Naukova dumka.

Avakian, Gr. 1924. Ştiri nouă din Tyras. Mănuşi de amfore, ţigle şi cărămizi cu ştampile. Cronica Numismatică şi arheologică V/№ 49-50: 3-22.

Avakian, Gr. 1927a. Ştiri nouă din Tyras. Graffiti. Cronica Numismatică şi arheologică VII/No 67-68: 4-17.

Avakian, Gr. 1927b. Ştiri nouă din Tyras. Graffiti ca exerciţii de scris. Cronica Numismatică şi arheologică VII/№ 71-72: 35-46.

Avakian, Gr. 1931. Săpăturile de la Cetatea-Albă. Comisiunea monumentelor istorice. Seçtia din Basarabia III: 47-104.

Batyushkov, P. N. 1892. Bessarabiya. Istoricheskoe opisanie. Sankt-Peterburg: Tipografiya Obshchestvennaya pol'za.

Batizat, G. V. 2001-2002. Novye svidetel'stva o kul'te egipetskikh bozhestv v Tire. Stratum plus 6: 202-209.

Batizat, G. V. 2003-2004. Misticheskie kul'ty v antichnoj Tire. Stratum plus 3: 340-351.

Batizat, G. V., Rosokhatskij, A. A. 2005. K izucheniyu mirovozzreniya naseleniya Tiry v antichnyj period. Visnyk Odeskoho istoryko-kraieznavchoho muzeyu: 4-22.

Bekker, P. V. 1849. Grazhdanskii byt tiritov pri rimskikh imperatorakh. Odessa: Tipografiia L. Nitche.

\footnotetext{
76 Savelieva, Saveliev 2012, 42-47; Savelieva, Saveliev 2015, 116-123; Saveliev, Savelieva 2012, 97-106; Saveliev, Savelieva 2017, 335-337; Saveliev 2013a, 285-290; Saveliev 2013b, 26-31; Saveliev 2013c, 544-547; Saveliev 2013d, 100-115; Saveliev 2014, 43; Saveliev 2015, 64-65; Kolesnychenko, Saveliev 2015, 34-45; Saveliev 2016a, 62-63; Saveliev 2016b, 251-255; Saveliev 2017a, 57-58; Saveliev 2017b, 119-134; Saveliev 2017c, 129-131; Saveliev 2018a, 123; Saveliev 2018b, 80-83; Saveliev 2018c, 92-93; Saveliev 2019a, 65-66; Saveliev 2019b.
} 
Bekker, P. 1850. Tiras i tirity. Zapiski Odesskogo obshchestva istorii i drevnostej 2: 416-469.

Bekker, P. V. 1853. Bereg Ponta Evksinskogo ot Istra do Borisfena. Zapiski Odesskogo obshchestva istorii $i$ drevnostej 3: 151-209.

Bruyako, I. V., Rosokhatskij, A. A. 2000. K sobraniyu svetilnikov rimskogo vremeni iz Tiry. Stratum plus 4: 342345.

Brun, F. 1853. O mestopolozhenii Tirasa, Zapiski Odesskogo obshchestva istorii i drevnostej 3: 47-66.

Chernenko, E. V., Zubar', V. M. and Son, N. A. 1989. Buterol' iz Tiry. Sovetskaya arkheologiya 2: $250-252$.

Dmytrov, L. D. 1949. Bilgorod-Dnistrovska arkheolohichna ekspedytsiya. Arkheolohichni pam 'iatky URSR II: 39-52.

Dmytrov, L. D. 1952. Rozkopky v m. Bilhorodi-Dnistrovskomu v 1947 r. Arkheolohichni pam'iatky URSR IV: 59-64.

Dmytrov, L. D. 1955. Osnovni pidsumky Izmailskoj arkheolohichnoj ekspedytsii 1949-1950 gg. Arkheolohichni pam'iatky URSR V: 111-123.

Furmanska, A. I. 1957. Arkheolohichni pam'iatky Tiry pershykh stolit' novoj ery. Arkheolohiya X: 80-93.

Furmanska, A.I. 1962. Rozkopky Tiry v 1958 r. Arkheolohichni pam 'yatky URSR XI: 122-137.

Furmanska, A.I. 1965. Reliefy vershnykiv z Tiry. Arkheolohiya XIX: 158-164.

Furmanskaya, A.I. 1960. Pamyatniki skul'ptury iz Tiry po raskopkam 1958 g. Kratkie soobshcheniya Instituta arkheologii Akademii nauk USSR 10: 78-83.

Furmanskaya, A.I., Antichnyj gorod Tira, in Boltunova, A. I. (red.), Antichnyi gorod, Izdatelstvo Akademii nauk SSSR: Moskva, 1963, 40-50.

Furmanskaya, A.I. 1964. Issledovanie Tiry, in Kratkie soobshcheniya Odesskogo gosudarstvennogo arkheologicheskogo muzeya 1962 g.: 56-63. Odessa: .

Furmanskaya, A. I. 1966. Tira. Svod arkheologicheskikh istochnikov G1-20: 35-36.

Furmanskaya, A. I. 1979. Raskopki Tiry v 1962-1963 gg., in Karyshkovskij, P. O. (ed.), Antichnaia Tira $i$ srednevekovyi Belgorod: 5-19. Kiev: Naukova dumka.

Furmanskaya, A. I. and Maksimov, E. V. 1955. Raskopki v Belgorode-Dnestrovskom. Kratkie soobshcheniia instituta arkheologii Akademii nauk USSR 4: 64-66.

Gudkova, A. V. 1989. Tira i osedloe naselenie Budzhaka v pervoj polovine I tys. n.e., in Gudkova, A.V. (ed.) Drevnee Prichernomor'e: 21-23. Odessa: Tipografiya MO.

Gudkova, A.V. 1991. Tira i chernyakhovskaya kul'tura, in Zaginailo, A. G. (ed.), Drevnee Prichernomor'e: 24-26. Odessa: Tipografiya oblastnogo upravleniya po pechati.

Gudkova, A. V., Klejman, I. B. and Son, N. A. 1979. Raskopki pozdneantichnoj Tiry, in Piotrovskii, B. B. (ed.) Problemy antichnoj istorii i kul 'tury II: 284-290. Erevan: Izdatel'stvo AN Armyanskoj SSR.

Gudkova, A. V. and Krapivina, V. V. 1990. Seroglinianaya keramika Tiry, Ol'vii i pamyatnikov chernyakhovskoj kul'tury. Kiev: Institut arkheologii.

Horokhovskyi, Ye. L. and Son, N. O. 1989. Fibuly z Tiry. Arkheolohiya 3: 69-78.

Yurgevich, V. N. 1883. Otkrytaia v 1881 g. v s. Chobruchi grecheskaya nadpis'drevnego goroda Tiry. Zapiski Odesskogo obshchestva istorii i drevnostej 13: 7-16.

Yurgevich, V.N. 1888. Zamechaniya o nekotorykh mestnostyakh Novorossijskogo kraya zasluzhivayushchikh arkheologicheskogo izucheniya. Trudy VI arkheologicheskogo sieezda 2: 29-41.

Yurgevich, V. N. 1889. Monety goroda Tiry, khranyashchiesya v muzee Odesskogo obshchestva istorii i drevnostej. Zapiski Odesskogo obshchestva istorii i drevnostej 15: 1-12.

Yurgevich, V.N. 1893. Kamni s nadpisyami, kuplennye dlya muzeya Obshchestva v 1892 g.. Zapiski Odesskogo obshchestva istorii i drevnostej 16: 11-13.

Karashevych, I. V., Karnaukh, Ye. H., Korpusova, V. M. and Son, N. O. 2007. Kolektsii doby rannogo zaliza ta antychnykh pam'yatok Pivnichnogo Prychornomor'ya, in Son, N. O. (ed.) Kolektsii Naukovykh fondiv Instytutu arkheolohii NAN Ukrainy. Katalog: 107-156. Kyiv: Akademperiodyka.

Karyshkovskij, P. O. and Klejman, I.B. 1985. Drevnij gorod Tira. Kiev: Naukova dumka.

Klejman, I.B. 1970. Statuetki iz Tiry. Svod arkheologicheskikh istochnikov G1-11: 25-27.

Klejman, I. B. 1971. Raskopki pomeshcheniya veksillyatsii Pervogo Italiiskogo legiona v Tire. Materialy po arkheologii Severnogo Prichernomor'ya 7: 229-238. 
Klejman, I. B. 1973. Materialy iz keramicheskikh kompleksov Tiry II-IV vv. n.e. Antichnye goroda Severnogo Prichernomor'ya i varvarskii mir: 16-18.

Klejman, I. B. 1975. Rimskaya tsitadel' v Tire, in Baran, V. D. (ed.) Novye otkrytiya sovetskikh arkheologov 2: 92-93. Kiev: .

Klejman, I. B. 1976. K stratigrafii naplastovanii rimskogo vremeni v Tire. Materialy po arkheologii Severnogo Prichernomor'ya 8: 109-119.

Klejman, I. B. 1978. Novaya grobnitsa v rajone Belgoroda-Dnestrovskogo i vopros o mestopolozhenii nekropolya Tiry, in Karyshkovskij, P. O. (ed.) Arkheologicheskie issledovaniya Severo-Zapadnogo Prichernomor'ya: 99-107. Kiev: Naukova dumka.

Klejman, I. B. 1980. Terrakoty iz raskopok Tiry 1970-1977 gg., in Karyshkovskij, P. O. (ed.) Issledovaniya po antichnoj arkheologii Yugo-Zapada Ukrainskoj SSR: 96-103. Kiev: Naukova dumka.

Klejman, I. B. 1984. O raskopkakh Tiry v 1940 g., in Dzis-Raiko, G. A. (ed.) Novye arkheologicheskie issledovaniya na Odeschine: 66-74. Kiev: Naukova dumka.

Klejman, I. B. 1985. Figurnyi sosud iz Tiry s podpisyu, in Dzis-Raiko, G.A. (ed.) Pamyatniki drevnej istorii Severo-Zapadnogo Prichernomor'ya: 59-62. Kiev: Naukova dumka.

Klejman, I. B. 1989. K izucheniyu vesovoj metrologii Tiry, in Samojlova, T. L. (ed.), Arkheologicheskie pamyatniki stepej Podnestrov'ya i Podunav'ya:19-25. Kiev: Naukova dumka.

Klejman, I. B. 1993. Tira: doissledovanie doma IV kontsa I - pervoj poloviny III veka n. e., in Okhotnikov, S. B. (ed.) Drevnee Prichernomor'e: 101-104. Odessa: Gortipografiya Odesskogo upravleniya po pechati.

Klejman, I. B. 1997. Pervye issledovateli Tiry: Ernst Romanovich Shtern i Paul Nikorescu, in Kryzhitskij, S. D. (ed.) Akkermanskie drevnosti 1: 256-269. Belgorod-Dnestrovskii: Iu. G -kompani.

Klejman, I. B. 1999. Ostatki kultovogo sooruzheniya v raspolozhenii rimskogo garnizona Tiry, in v Okhotnikov, S.B. (red.) Kratkie soobshcheniya Odesskogo arkheologicheskogo obshchestva:104-107. Odessa: TES.

Klejman, I. B. and Kotsievskij, A. S. 1991. Gemmy iz Tiry (Materialy k izucheniyu kul'turnykh kontaktov), in Vanchugov, V. P. (ed.) Severo-Zapadnoe Prichernomor'e - kontaktnaya zona drevnikh kul'tur: 95-99. Kiev: Naukova dumka.

Klejman, I. B. and Son, N.A. 1983. Zapadnopontiiskie i provintsial'no rimskie kulturno-ekonomicheskie svyazi Tiry, in Dzis-Raiko, G., A. (ed.) Materialy po arkheologii Severnogo Prichernomor'ya: 47-59. Kiev: Naukova dumka.

Knauer, F. I. 1892. Spisok arkheologicheskikh predmetov, najdennykh v raznykh mestakh Akkermanskogo uezda. Chteniya $v$ istoricheskom obshchestve Nestora letopistsa 6: 12-13.

Kochubinskij, A. A. 1901. Tura (Tiras) - Belgorod - Akkerman i ego novaya lapidarnaya nadpis' ot 1454 g. Zapiski Odesskogo obshchestva istorii i drevnostej 23: 79-198.

Kochubinskij, A. A. and Shtern, E. R. 1896. O poezdke v Akkerman dlya issledovaniya tam otkrytoj grobnitsy. Zapiski Odesskogo obshchestva istorii i drevnostej 19: 13-16.

Kolesnychenko and A. M., Saveliev, O. K. 2015. Sklyanky z napysom KATAXAIPE KAI EYФPAINOY iz rozkopok Tiry ta problema yikh pokhodzhennya. Arkheolohiya 4: 34-45.

Kondakov, N. P. 1876. O nekotorykh melkikh predmetakh drevnosti, najdennykh v Akkermane v 1867 g. Trudy II arkheologicheskogo sieezda 1/III: 20-24.

Kravchenko, N. M. 1973. K voprosu o vzaimosvyaziakh pozdneantichnoj Tiry i varvarskikh plemen (chernyakhovskaya kul'tura). Antichnye goroda Severnogo Prichernomorya i varvarskij mir: 19-21.

Kravchenko, N. M. and Korpusova, V. M. 1975. Deyaki rysy material'noj kul'tury piznorymskoj Tiry. Arkheolohiya 18: 20-42.

Krapivina, V. V. 2008. O razgrome Tiry v pervoj polovine III v. n.e. Drevnee Prichernomor'e VIII: 191-198.

Krapivina, V. V. 2009. Tira, Ol'viya i varvary v III v. n. e., in Kopylov, V.P. (ed.) Mezhdunarodnye otnosheniya v bassejne Chernogo morya v skifo-antichnoe i khazarskoe vremya: 196-205. Rostov-na-Donu: Media-Polis.

Krapivina, V. V. 2012. Domashnie svyatilishcha antichnykh pamyatnikov Severnogo Prichernomor'ya. Bosporskie issledovaniya XXVI: 182-217.

Kryzhitskij, S. D. and Klejman, I. B. 1971. Otkrytie oboronitel'nykh sooruzhenij Tiry. Arkheologicheskie otkrytiya 1970 g.: 258-259.

Kryzhytskyi, S. D. and Klejman, I. B. 1978. Zhytlovyi budynok i ukriplennya Tiry pershykh stolit nashoj ery. Arkheolohiya 28: 83-96. 
Levina, E. A. and Ostroverkhov, A. S. 1989. Okonnoe steklo v arkhitekture antichnykh gorodov Severnogo Prichernomor'ya, in Koshelenko, G.A. (ed.) Kratkie soobshcheniya issledovanij antichnykh gorodov: 67-69. Moskva: .

Maksimov, E. V. 1955. Novyj pamyatnik pervykh vekov nashej ery v Tire. Kratkie soobshcheniya Instituta arkheologii Akademii nauk USSR 5: 80-83.

Masyuta, D. O. 2018. Pro odyn ridkisnyj typ amfor rymskoho chasu z Tiry. Arkheolohiya 3: 99-106.

Masyuta, D.A. 2019a. Amfory tipa 27 po klassifikatsii V. V. Krapivinoi iz Tiry. Eminak 1 (25): 138-148.

Masyuta, D.A. 2019b. Psevdorodosskie amfory iz Tiry (II pervaya polovina III vv. n.e). Revista Archeologică $X V / 2: 100-110$.

Murzakevich, N. N. 1844. O nekotorykh maloizvestnykh monetakh imeyushchikhsya v Odesse. Zapiski Odesskogo obshchestva istorii i drevnostej 1: 315-319.

Nicorescu, P. 1924. Scavi e scoperte a Tyras, Ephemeris Dacoromana 2 :378-415.

Nicorescu, P. 1933. Fouilles de Tyras. Dacia III-IV: 557-601.

Nicorescu, P. 1937. Garnizoana romană în sudul Basarabiei. Academia Română. Memoriile Secţiunii Istorice 19: 217-239.

Nicorescu, P. 1944. O inscripţie a împăratului Traian găsită la Cetatea Albă. Academia Română. Memoriile Secţiunii Istorice 26: 501-510.

Otchet Odesskogo Obshchestva istorii i drevnostej s 14 noyabrya 1859 po 14 noyabrya 1860 g., Odessa, 1861.

Parmakli, S. I. and Russev, N. D. 1999. K istorii izucheniya antichnykh pamyatnikov Bessarabii. Stratum plus 3: 359-368.

Pavlenko, Yu. V. and Son, N. O. 1991. Piznoantychna Tira ta rannoderzhavne ob'iednannya vizigotiv. Arkheologhiya 2: 6-16.

Rabinovich, M.G. 1968. Issledovanie srednevekovykh sloev Belgoroda Dnestrovskogo v 1954 i 1958 gg. Kratkie soobshcheniya instituta arkheologii 113: 102-107.

Rosokhatskij, A. A., Shterbul, N. A. 1991. Kamennyi sklep iz okrestnostej Tiry, in v Zaginajlo, A. G. (ed.) Drevnee Prichernomor'e: 78-80. Odessa: Gorodskaya tipografiya oblasnogo upravleniya po pechati.

Samojlova, T. L. 1978. Osnovnye tipy amfor I-IV vv. n. e. iz Tiry, v Karyshkovskij, P. O. (ed.) Arkheologicheskie issledovaniya Severo-Zapadnogo Prichernomor'ya: 254-266. Kiev: Naukova dumka.

Samojlova, T. L. 2007. Osnovni pidsumky robit na pam'iattsi Tira-Bilgorod i podalshi perspektyvy doslidzhennya. Arkheolohichni doslidzhennya Lvivskogo universytetu 10: 120-130.

Samojlova, T. L. 2008a. Issledovaniya poslednikh let antichnoj Tiry i problemy ee izucheniya, in Ewdoksia PapuciWładyka (ed.) PONTIKA 2006. Najnowcze badania greckich kolonii pótnocnych wybrzeży Morza Czarnego: 161175. Kraków: Jagiellonian University.

Samojlova, T. L. 2008b. Novye dannye o pozdneantichnoj Tire. Kratkie soobshcheniia Odesskogo arkheologicheskogo obshchestva: 140-143.

Samojlova, T. L. 2013. Tira, in Bruyako, I. V. and Samojlova, T. L. (eds.), Drevnie kultury Severo-Zapadnogo Prichernomor'ya (k 95 letiyu Natsional'noj akademii nauk Ukrainy): 450-492. Odessa: SMIL.

Samojlova, T. L., Cojocaru, V. and Boguslavskii, G. S., Antichnaya Tira - srednevekovyi Belgorod (otchet o raskopkakh za 1996-1999 gg.), in Cojocaru, V., Samojlova, T. L. (eds.), Tyras Cetatea Albă / Belgorod-Dnistros 'kyj, Redacţia publicaţiilor pentru străinătate: Bucureşti, 2002, 159-189.

Samojlova, T. L., Cojocaru, V., Smolyaninova, S. P., Boguslavskii, G. S., Ostapenko, P. V., Raskopki TiryBelgoroda v 2002 g., Arkheolohichni vidkryttia v Ukraini v 2001-2002 rr., 2003, 249-253.

Samojlova, T., Ostapenko, P., Grey clay ceramics from Tyras, Pontica, XLII, 2009, 53-65.

Samojlova, T. L., Ostapenko, P. V. and Saveliev, O. K., Novejshie otkrytiya v antichnoj Tire, in Maslennikov, A. A. et al. (eds.) IYMBOАA. Antichnyj mir Severnogo Prichernomor'ya. Novejshie nakhodki i otkrytiya 1: 216-219. Moskva-Kiev: ID «Triumf print».

Saveliev, O. K. 2013a. Mifologicheskie syuzhety na krasnolakovoj keramike iz Tiry. Stratum plus 3: 285-290.

Saveliev, O. K. 2013b. O vzaimootnosheniyakh Tiry i sarmatov, in Smyntyna, E. V. (ed.) Varvarskij mir severopontijskikh zemel' v sarmatskuyu epokhu. Sbornik statei k 60-letiiu A.N. Dzigovskogo: 26-31. Kiev: Vydavets Oleg Filyuk.

Saveliev, O. K. 2013c. Portretnye relefnye izobrazheniya na keramike rimskogo vremeni iz Tiry, in Nemchenko, I. V. (ed.) Drevnee Prichernomor'e X: 544-547. FLP «A. S. Fridman»: Odessa. 
Saveliev, O. K. 2013d. Fibuly z Tiry (znakhidky 1996-2010 rr.). Arkheolohiya 2: 100-115.

Saveliev, O. K. 2014. Kontakty Tiry i varvarov v rimskoe vremya, in Leviki, O., et al. (eds.), Probleme actuale ale arheologiei, etnologiei şi studiului artelor: 43. Chişinău: Garomont.

Saveliev, O. K. 2015. K voprosu o kontaktakh Tiry i germantsev, in Ghilaş, V., et. al. (eds.) Probleme actuale ale arheologiei, etnologiei şi studiului artelor: 64-65. Chişinău: Tipogr. «Notograf Prim».

Saveliev, O. K. 2016a. Rimskie kostyanye tessery iz Tiry. Eminak. FORUM OLBICUM I. Pamyati V.V. Krapivinoj 4 (16): 251-255.

Saveliev, O.K. 2016b. Rimskii import I v. n.e. v Tire, în Ghilaş, V., et. al. (eds.), Probleme actuale ale arheologiei, etnologiei şi studiului artelor: 62-63. Chişinău: Tipogr. «Notograf Prim».

Saveliev, O. K. 2017a. K kharakteristike rimskogo garnizona v Tire, in Ghilaş, V., et. al. (eds.), Probleme actuale ale arheologiei, etnologiei şi studiului artelor: 57-58. Chişinău: Tipogr. «Notograf Prim».

Saveliev, O. K. 2017b. Rimskij import I v. n. e. v Tire i nekotorye voprosy rimsko-varvarskikh kontaktov v SeveroZapadnom Prichernomor'e. Stratum plus 4: 119-134.

Saveliev, O. K. 2017c. «Skifskie» voiny, varvary i Tira, in Savinov, in D. G. (ed.) Rannii zheleznyj vek ot rubezha er do serediny I tys. n. e. Dinamika osvoeniya kulturnogo prostranstva: 129-131. Sankt-Peterburg: «Skifiia-print».

Saveliev, O. K. 2018a. Importna produktsiya Tiry I - pochatku V st. n. e., in Chabaj, V. P. (ed.), I Vseukrainskyi arkheolohichnyi z'izd: 123. Kyiv: Vydavnytstvo.

Saveliev, O.K. 2018b. Osnovnye tipy posudy gruppy pontic sigillata v keramicheskom komplekse Tiry, in Smyrnov, V. I. (ed.) FORUM OLBICUM II: pamyati V.V. Krapivinoj (do 150-richchya doslidzhennya Olvii): 8083. Mykolaiv: NDTs «Lukomorie».

Saveliev, O. K. 2018c. Torgovye svyazi Knida i Tiry v pervykh vekakh n. e. (po dannym keramicheskikh izdelij), in Ghilaş, V., et. al. (eds.), Probleme actuale ale arheologiei, etnologiei şi studiului artelor: 92-93. Chişinău: Tipogr. «Notograf Prim».

Saveliev, O. K. 2019a. K istorii Tiry v pozdnerimskuyu epokhu, în Ghilaş, V., et. al. (eds.), Probleme actuale ale arheologiei, etnologiei şi studiului artelor, Tipogr. «Notograf Prim»: Chişinău, 2019, 65-66.

Saveliev, O. K. 2019b. Material'na kul 'tura Tiry (I-pochatok Vst. n.e.). Kyiv: Dysertatsiya na zdobuttya stupenya kandydata istorychnykh nauk.

Saveliev, O. K. and Savelieva, E. S. 2012. Terrakoty i figurnye sosudy rimskogo vremeni iz Tiry (raskopki 19972011 gg.). Stratum plus 4: 97-106.

Saveliev, O. K. and Savelieva, E. S. 2017. Neskol'ko terrakot rimskogo vremeni iz Tiry, in Prigarin, A. A. (ed.) Chelovek $v$ istorii i kul'ture 3: 335-337. Odessa: Irbis.

Savelieva, K. S. and Saveliev, O. K. 2012. Terakotovi statuetky rymskykh voiniv z Pivnichno-Zakhidnoho Prychornomor'ya. Arkheolohiya 3: 42-47.

Savelieva, E. S. and Saveliev, O. K. 2015. Terrakotovye statuetki rimskikh voinov v Severnom Prichernomor'e. Terra Alustiana MMXI: 116-123.

Shtaerman, E. M. 1951. Keramicheskie klejma iz Tiry (V svyazi s voprosom o klejmakh neizvestnykh tsentrov). Kratkie soobshcheniya instituta istorii material'noj kul'tury XXXVI: 31-49.

Shtern, E.R. 1901. O poslednikh raskopkakh v Akkermane. Zapiski Odesskogo obshchestva istorii i drevnostei XXIII: 33-61.

Shtern, E. R. 1913. Raskopki v Akkermane letom 1912 g. Zapiski Odesskogo obshchestva istorii i drevnostei XXXI: 92-101.

Smolyaninova, S. P. 2005. Lyvarni formy z Tiry. Arkheolohiya 1: 82-91.

Son, N. A. 1980. Grecheskie kul'ty Tiry pervykh vekov n. e., in Anokhin, V.A. (ed.) Issledovaniya po antichnoj arkheologii Severnogo Prichernomor'ya: 125-140. Kiev: Naukova dumka.

Son, N. A. 1986. Iz istorii pozdneantichnoj Tiry, in Anokhin, V. A. (ed.), Antichnaya kul'tura Severnogo Prichernomor'ya v pervye veka nashei ery: 142-153. Kiev: Naukova dumka.

Son, N. O., Sklyani posudyny z Tiry, Arkheolohiya, 63, 1988, 47-56.

Son, N. A. 1993. Tira rimskogo vremeni. Kiev: Naukova dumka.

Son, N. A. 1995. Goncharnye kompleksy Tiry, in Okhotnikov, S. B. (ed.) Problemy istorii i arkheologii Nizhnego Podnestrov'ya : 60-62. Belgorod-Dnestrovskij : editura.

Son, N. A. 1997. Ob osobennostyakh vneshnej torgovli Tiry v pervye veka n. e., in Yarovoi, E. V. (ed.) Chobruchskij 
arkheologicheskij kompleks $i$ voprosy vzaimovliyaniya antichnoj i varvarskoj kul'tury IV v. do n.e. - IV v. n.e.: 3033. Tiraspol: editura.

Son, N. A. 2002. Ob osnovnykh tendentsiyakh sotsial'no-ekonomicheskogo razvitiya Tiry v I - seredine III vv., in Tolochko, P. P. (ed.), Severnoe Prichernomor'e v antichnoe vremya: 121-131. Kiev: Institut arkheologii NAN Ukrainy.

Son, N.A. 2010. Kostyanye izdeliya iz Tiry, in Zinko, V. N. (ed.) Bospor Kimmeriiskij i varvarskij mir v period antichnosti i srednevekovya. Remesla i promysly : 419-422. Kerch: Kerchenskaya gorodskaya tipografiia.

Son, N. A. 2011. Kostyanye izdeliya iz Tiry. Bosporskie issledovaniya XXV: 298-311.

Son, N. O. and Nazarov, V. V. 1993. Znakhidky rymskoj zbroi v Tiri ta Olvii. Arkheolohiya 1: 120-123.

Son, N. A. and Shaptsev, M. S. 2011. Keramicheskie figurnye sosudy iz raskopok Tiry, in Zinko, V.,N. (ed.) Bosporskie chteniya. Bospor Kimmerijskij i varvarskii mir v period antichnosti i srednevekov'ya. Vzaimovliyanie kul'tur: 361-363. Kerch: Demetra.

Son, N. A. and Shaptsev, M. S. 2012. Krasnolakovaya keramika iz Tiry. Arkheolohiya i davnya istoriya Ukrainy 8: 83-103.

Son, N. O. and Shejko, I. M. 2016. Metalevi svitylnyky z Olvii ta Tiry. Arkheolohiya 4: 79-87.

Son, N. O. and Shejko, I. M. 2018. Lipni svitylnyky z Tiry. Arkheolohiya i davnya istoriya Ukrainy 3 (28): 140146.

Son, N. A. and Sorochan, S. B. 1988. Antichnye svetil'niki iz Tiry, in Anokhin, V. A. (ed.) Antichnye drevnosti Severnogo Prichernomor'ya: 115-133. Kiev: Naukova dumka.

Stempkovskij, I. A. 1826. Issledovaniya o mestopolozhenii drevnikh grecheskikh poselenij na beregakh Ponta Evksinskogo mezhdu Tirasom i Borisfenom. Sankt-Peterburg: Tipografiia A. Smirtsina.

Struve, O. 1867. Arkheologicheskie zametki po povodu poseshcheniya Akkermana i ego okrestnostej v letnee vremya 1866 g. Zapiski Odesskogo obshchestva istorii i drevnostei 6: 605-611.

Tira-Belgorod-Akkerman (materialy issledovanij), Pechatnyi dom: Odessa.

Trejster, M. Yu. 2000. K nakhodkam metallicheskikh detalej rimskogo voennogo kostyuma i konskoj sbrui $\mathrm{V}$ Severnom Prichernomor'e. Rossijskaya arkheologiya 2: 156-164.

Zubar, V. M. and Son, N. O. 1999. Novi arkheolohichni dani pro rym'sku zalogu Tiry. Arkheolohiya 3: 118-123.

OLEG SAVELIEV, Institute of Archeology, National Academy of Sciences of Ukraine sav_reun@ukr.net 